J-SANAK: Jurnal Kajian Anak

(p-ISSN: 2686-5343 le-ISSN: 2715-7989

Vol. (2)(01), (Juli-Desember)(2020), (Halaman)(1-13)

DOI: https://doi.org/10.24127/j-sanak.v2i01.360

\title{
PENINGKATAN MINAT BELAJAR DAN SIKAP SAINS ANAK MELALUI METODE EKSPERIMEN PADA MASA PANDEMI COVID 19
}

\author{
Erna Roostin ${ }^{1}$ \\ STKIP Sebelas April Sumedang \\ Ernaroostin@ymail.com
}

\begin{abstract}
ABSTRAK
Penelitian ini bertujuan untuk mendeskripsikan peningkatan minat belajar dan sikap sains anak kelompok B Kober Nurjaman di Kecamatan Tanjungkerta Kabupaten Sumedang Jawa Barat. Adapun permasalahan dalam penelitian ini adalah rendahnya minat belajar anak yang meliputi kurangnya keinginan anak untuk ikut berpartisipasi dalam kegiatan pembelajaran dan juga kurangnya sikap sains anak yang meliputi sikap anak untuk berfikir kritis terhadap segala sesuatu yang terjadi dalam pembelajaran sains. Metode yang digunakan dalam penelitian ini adalah metode penelitian tindakan kelas (PTK) model Kemmis dan Mc Taggart, penelitian ini terdiri dari 4 tahap yaitu perencanaan, pelaksanaan, pengamatan, dan refleksi. Adapun subjek dalam penelitian ini adalah anak anak Kober Nurjaman Desa Banyuasih Kecamatan Tanjungkerta Kabupaten Sumedang tahun pelajaran 2019/2020, sebanyak 12 orang anak, dan sesuai dengan judul di atas, penelitian ini dilaksanakan melalui daring/online mengingat adanya wabah Virus Corona Desember 2019 (COVID-19). Berdasarkan hasil analisis data diketahui minat belajar anak meningkat dari data awal 0\%, siklus I 33\%, siklus II 58\%, dan siklus III $91 \%$. Demikian juga sikap sains anak mengalami peningkatan dari data awal $0 \%$, siklus I 25\%, siklus II 50\%, dan siklus III 91\%. Berdasarkan hasil analisis data tersebut dapat disimpulkan bahwa terdapat peningkatkan minat belajar dan sikap sains anak.
\end{abstract}

Kata Kunci: Minat Belajar, Sikap Sains, Metode Eksperimen Received 10-11-2020; Received in revised form 31-10-2020; Accepted 01-11-2020

\begin{abstract}
This study aims to describe the increase in interest in learning and science attitudes of the children of group B Kober Nurjaman in Tanjungkerta District, Sumedang Regency, West Java, after applying the experimental method in science learning. The method used in this research is the classroom action research method (PTK) model of Kemmis and Mc Taggart, this research consists of 4 stages, namely planning, implementing, observing, and reflecting. The subjects in this study were the children of Kober Nurjaman, Banyuasih Village, Tanjungkerta District, Sumedang Regency in 2019/2020, as many as 12 children. and following the above statement, this research was conducted online considering the COVID-19 outbreak. From the results of data analysis, it is known that the experimental method can increase children's learning interest and scientific attitudes. Based on the results of data analysis, it is known that children's learning interest has increased from $0 \%$ initial data, $33 \%$ first cycle, $58 \%$ second cycle, and $91 \%$ third cycle. Likewise,
\end{abstract}


J-SANAK: Jurnal Kajian Anak

(p-ISSN: 2686-5343 |e-ISSN: 2715-7989

Vol. (2)(01), (Juli-Desember)(2020), (Halaman)(1-13)

DOI: https://doi.org/10.24127/j-sanak.v2i01.360

children's scientific attitudes have increased from $0 \%$ initial data, 25\% first cycle, $50 \%$ second cycle, and $91 \%$ third cycle. Based on the results of the data analysis, it can be concluded that there is an increase in children's interest in learning and science attitudes.

Keywords: Learning Interest, Science Attitude, Experimental Method

\section{A. PEndahuluan}

Pendidikan anak usia dini merupakan suatu upaya pembinaan yang ditujukan kepada anak usia 0-6 tahun dengan memberikan rangsangan pendidikan agar anak siap memasuki jenjang pendidikan yang lebih lanjut. Tujuan utama dari pendidikan anak usia dini adalah untuk membentuk anak Indonesia yang berkualitas melalui pemberian stimulasi guna menumbuh kembangkan seluruh aspek perkembangan anak agar dapat tumbuh dan berkembang secara optimal.

Sebagian besar masyarakat dalam hal ini orang tua berpandangan bahwa perkembangan fisik anak merupakan salah satu aspek yang harus diutamakan, namun seharusnya selain pentingnya perkembangan fisik, perkembangan psikis anak juga tidak kalah penting bagi kesiapan mental anak yang harus dipersiapkan sejak dini, karena pada dasarnya kesiapan mental yang kurang akan menyebabkan terhambat nya proses kegiatan pembelajaran pada anak sehingga beresiko pada lemahnya partisipasi anak terhadap kegiatan pembelajaran serta akan merambat pada seluruh aspek pendukung lainnya (Roostin \& Swandhina, 2019).

Salah satu aspek yang dihasilkan dari kuatnya psikis anak yaitu minat belajar. Minat yang berarti kesukaan, perhatian, (kecenderungan hati pada sesuatu) keinginan. Jadi dalam proses belajar siswa harus mempunyai minat atau kesukaan untuk mengikuti proses pembelajaran, karena dengan adanya minat akan mendorong siswa untuk menunjukkan perhatian, aktivitasnya, dan partisipasinya dalam mengikuti pembelajaran yang sedang berlangsung, (Slameto, 2015) mengatakan mengenai pengertian belajar secara psikologis merupakan suatu proses perubahan yaitu perubahan tingkah laku sebagai hasil dari interaksi dengan lingkungannya dalam memenuhi kebutuhan hidupnya.

Pendidikan anak usia dini, merupakan pendidikan yang memfasilitasi anak agar anak mampu menanamkan dan meningkatkan sikap kritis dalam dirinya, salah satunya adalah melalui pembelajaran sains. Sains ini sangat penting diintegrasikan pada anak, karena pada dasarnya seorang anak yang telah memiliki sikap sains akan senantiasa berfikir kritis terhadap apa yang terjadi dalam dirinya dan lingkungannya. (Khaeriyah et al., 2018) mengemukakan bahwa tujuan pembelajaran sains bagi anak usia dini diantaranya yaitu (1) agar anak-anak memiliki kemampuan memecahkan masalah yang dihadapinya melalui penggunaan sains, (2) agar anak memiliki sikap-sikap ilmiah, (3) agar anak 
J-SANAK: Jurnal Kajian Anak

(p-ISSN: 2686-5343 |e-ISSN: 2715-7989

Vol. (2)(01), (Juli-Desember)(2020), (Halaman)(1-13)

DOI: https://doi.org/10.24127/j-sanak.v2i01.360

mendapatkan pengetahuan dan informasi ilmiah, (4) agar anak- anak menjadi lebih berminat dan tertarik untuk menghayati sains yang ada di lingkungan.

Pada dasarnya anak usia dini telah memiliki sikap rasa ingin tahu dan sikap sains dalam dirinya. Karena sikap rasa ingin tahu dan sikap sains merupakan salah satu karakteristik anak. Sikap rasa ingin tahu yang tinggi terbentuk oleh adanya sesuatu yang menarik perhatiannya, rasa ingin tahu penting dikembangkan untuk memberikan pengetahuan yang baru bagi anak dalam rangka mengembangkan daya fikir nya. Sikap rasa ingin tahu dan sikap sains itu sendiri akan berkembang dengan baik apabila disertai dengan pemberian stimulasi yang baik pula (Roostin, 2015). Sehingga hal ini dirasa penting bagi anak untuk bekal memasuki pendidikan sekolah dasar nanti. Selain itu dengan meningkatnya sikap sains anak, diharapkan dapat menjadikan anak pribadi yang memiliki sikap kritis tinggi, dan dapat menghadapi tantangan zaman di masa dewasa nya, Maka dari itu perlu adanya stimulasi untuk mengembangkan sikap sains pada anak secara terarah dan terencana sesuai dengan perkembangan anak.

Adapun permasalahan dalam penelitian ini adalah rendahnya minat belajar anak yang meliputi kurang adanya keinginan anak untuk ikut berpartisipasi dalam kegiatan pembelajaran dan juga kurangnya sikap sains anak yang meliputi sikap anak untuk berfikir kritis terhadap segala sesuatu yang terjadi dalam pembelajaran sains. Penyebab rendahnya minat belajar dan sikap sains anak terhadap pembelajaran sains yang diberikan oleh guru, salah satunya adalah dikarenakan dalam penggunaan metode pada saat pembelajaran sains hanya menggunakan satu metode saja selama beberapa tahun terakhir, Kober Nurjaman Desa Banyuasih Kecamatan Tanjungkerta ini belum pernah menggunakan metode alternatif lainnya, sehingga anak terkesan merasa bosan dan terlihat kurang antusias dalam dalam mengikuti kegiatan pembelajaran sains yang disajikan, hal ini menjadi salah satu rendahnya minat belajar dan dikap sains pada anak.

Oleh karena itu meningkatnya minat belajar dan sikap sains anak dalam pembelajaran sains merupakan tujuan penelitian ini dan juga harapan besar bagi peneliti sehingga peneliti merasa bahwa penelitian ini penting dilakukan guna mendapatkan solusi terkait rendahnya minat belajar dan sikap sains anak di Kober Nurjaman di kelompok B ini yang berjumlah 12 anak.

Dalam penelitian ini peneliti akan menggunakan salah satu metode pembelajaran eksperimen yang akan digunakan dalam pembelajaran sains sebagai salah satu alternatif dan solusi guna menyelesaikan permasalahan yang terjadi pada anak kelompok B Kober Nurjaman Desa Banyuasih Kecamatan Tanjungkerta.

Menurut Yeni yang dikutip dalam (Khaeriyah et al., 2018) mengatakan bahwa metode eksperimen (percobaan) adalah cara penyajian pembelajaran dimana anak melakukan percobaan dengan mengalami dan membuktikan sendiri sesuatu 
J-SANAK: Jurnal Kajian Anak

(p-ISSN: 2686-5343 |e-ISSN: 2715-7989

Vol. (2)(01), (Juli-Desember)(2020), (Halaman)(1-13)

DOI: https://doi.org/10.24127/j-sanak.v2i01.360

pertanyaan atau hipotesis yang dipelajarinya, melalui metode ini anak dapat mengetahui cara atau proses terjadinya sesuatu dan mengapa sesuatu itu dapat terjadi serta bagaimana mereka menemukan solusi terhadap permasalahan yang ada dan pada akhirnya mereka dapat membuat sesuatu bermanfaat dari kegiatan tersebut.

Melalui metode eksperimen ini diharapkan anak akan memperoleh pengetahuan baru yang didapatnya dari hasil percobaan pembelajaran dengan metode eksperimen, sehingga anak dapat mengamati prosesnya, serta menarik kesimpulan dari apa yang telah dilakukannya dalam pembelajaran percobaan melalui metode eksperimen tersebut. Eksperimen juga merupakan keterampilan yang banyak dihubungkan dengan sains (Ilmu pengetahuan) (Ratunguri, 2016). Selain itu diharapkan minat belajar dan sikap sains anak akan meningkat dengan penggunaan metode eksperimen ini.

Dengan adanya pandemi corona virus (COVID-19), maka peneliti akan melakukan penelitian dengan media yang telah disepakati oleh orangtua. Peran orangtua disini adalah untuk membantu berjalannya penelitian yang akan dilakukan melalui gadget orangtua peserta didik, sehingga peneliti terlebih dahulu telah berkoordinasi dengan orangtua peserta didik guna berjalannya penelitian ini dengan baik. Dengan demikian sesuai kesepakatan peneliti dan orangtua peserta didik, penelitian ini akan dilakukan melalui perekaman kegiatan anak melalui aplikasi video yang nantinya akan direkam oleh orangtua lalu di kirimkan pada peneliti.

\section{B. METODOLOGI}

Metode penelitian yang digunakan dalam penelitian ini adalah metode penelitian tindakan kelas (Suharsimi, 2006) bahwa, "Penelitian Tindakan Kelas (PTK) merupakan perencanaan terhadap kegiatan belajar berupa sebuah tindakan yang sengaja dimunculkan dan terjadi dalam sebuah kelas secara bersama”. Untuk mempermudah kegiatan penelitian ini, peneliti harus menggunakan desain penelitian. Desain penelitian merupakan acuan kerja dalam melaksanakan kegiatan pembelajaran. Desain penelitian dituangkan ke dalam model tindakan. Desain penelitian yang digunakan dalam penelitian ini adalah desain penelitian tindakan kelas (Classroom Action Research), yang diadaptasi dari Kemmis dan Mc. Taggart dalam buku Arikunto, Model Kemmis dan Taggart, terdiri dari empat komponen, yaitu perencanaan (planning), pelaksanaan (acting), pengamatan (observesing), dan refleksi (reflecting). Secara rinci prosedur pelaksanaan ini dapat diuraikan sebagai berikut :

Perencanaan (planning) disusun berdasarkan masalah yang akan dipecahkan agar terjadi perubahan dan peningkatan minat belajar dan sikap sains anak tahap ini meliputi kegiatan identifikasi masalah, mencari informasi mengenai alternatif 
J-SANAK: Jurnal Kajian Anak

(p-ISSN: 2686-5343 |e-ISSN: 2715-7989

Vol. (2)(01), (Juli-Desember)(2020), (Halaman)(1-13)

DOI: https://doi.org/10.24127/j-sanak.v2i01.360

tindakan yang akan diambil untuk memperbaiki praktek pembelajaran yang masih kurang, menetapkan tujuan, menyusun perencanaan pelaksanaan pembelajaran (RPPH) yang terdiri dari kegiatan awal, kegiatan inti, dan kegiatan akhir., mempersiapkan perangkat yang dibutuhkan selama proses pembelajaran, dan menetapkan aturan kegiatan pembelajaran.

Pelaksanaan (acting) tindakan dilakukan dalam pembelajaran melalui penerapan metode eksperimen yang didasarkan atas pertimbangan teoritis dan empiris agar minat belajar dan sikap sains anak meningkat. Pelaksanaan tindakan ini merupakan proses kegiatan pembelajaran sebagai realisasi dari teori dan strategi belajar mengajar yang telah disiapkan serta mengacu pada kurikulum yang berlaku, dan hasil yang diperoleh diharapkan dapat meningkatkan refleksi dan evaluasi terhadap apa yang terjadi di kelas.

Pengamatan (observing) dilaksanakan saat pelaksanaan tindakan untuk mengumpulkan data dan informasi yang diperlukan selama proses pembelajaran. Dari kegiatan pengamatan ini akan diketahui secara jelas mengenai kinerja guru dan aktifitas siswa yang terekam menggunakan instrument berupa format observasi, yaitu melaksanakan pengamatan menggunakan instrumen data yang telah disusun sebelumnya untuk meningkatkan minat belajar dan sikap sains anak melalui penggunaan metode PTK.

Refleksi (reflecting) merupakan bagian yang penting untuk memahami dan memberikan makna terhadap proses dan hasil (perubahan) yang terjadi sebagai akibat adanya tindakan yang dilakukan. Dalam tahap refleksi segala informasi yang terkumpul perlu diurai, dicari kaitan antar yang satu dengan yang lainnya. Hasil refleksi ini sebagai bahan perbaikan pada siklus selanjutnya dikaitkan dengan teori atau hasil penelitian yang relevan.

Subjek penelitian ini adalah anak kelompok B Kober Nurjaman Desa Banyuasih Kecamatan Tanjungkerta Kabupaten Sumedang tahun pelajaran 2019/2020, yang terdiri dari 12 anak, yang terdiri dari 5 orang anak laki-laki dan 7 orang anak perempuan.

Adapun teknik pengumpulan data yang akan digunakan dalam penelitian ini yaitu:

\section{a. Teknik observasi}

Teknik Observasi ini digunakan peneliti untuk mendapatkan data yang sesuai dengan tujuan yang tercantum dalam perencanaan pembelajaran yang mencakup sikap anak saat proses pembelajaran, serta aktivitas anak dan antusiasme pada saat.

Proses pembelajaran kegiatan menggunakan metode eksperimen berlangsung. Observasi ini dilakukan oleh peneliti setelah orangtua mengirimkan video pembelajaran anak untuk meningkatkan minat belajar dan sikap sains anak di Kober Nurjaman Kecamatan Tanjungkerta Kabupaten Sumedang. 
J-SANAK: Jurnal Kajian Anak

(p-ISSN: 2686-5343 |e-ISSN: 2715-7989

Vol. (2)(01), (Juli-Desember)(2020), (Halaman)(1-13)

DOI: https://doi.org/10.24127/j-sanak.v2i01.360

\section{b. Teknik Dokumentasi}

Teknik dokumentasi ini bertujuan untuk mengarsipkan dokumentasi berupa foto yang dapat dijadikan bukti terhadap pelaksana penelitian itu sendiri. Adapun teknik dokumentasi yang digunakan dalam penelitian ini adalah berupa rekaman video dan pengambilan foto anak melalui gadget orangtua anak pada saat anak melakukan pembelajaran sains menggunakan metode eksperimen.

Penelitian Tindakan Kelas (PTK) ini di laksanakan mulai bulan Maret sampai dengan Agustus 2020. Waktu untuk penelitian ke lapangan dilaksanakan pada bulan Juni 2020. Namun sebelumnya peneliti sampaikan bahwa mengingat keadaan di Indonesia bahkan di dunia kini sedang mengalami wabah pandemi COVID-19, sehingga peneliti dalam pengambilan data hanya akan melaksanakan penelitian melalui daring (online) dengan menggunakan teknologi informasi komunikasi yang ada. Kisi-kisi instrumen peningkatan minat belajar dan sikap sains anak adalah sebagai berikut:

Tabel 1. Kisi-kisi Instumen Penelitian Minat Belajar dan Sikap Sains

\begin{tabular}{|c|c|c|c|c|c|}
\hline Variabel & $\begin{array}{c}\text { Sub } \\
\text { Variabel }\end{array}$ & Indikator & $\begin{array}{c}\text { Teknik } \\
\text { pengump } \\
\text { ulan data }\end{array}$ & $\begin{array}{c}\text { Sumber } \\
\text { Data }\end{array}$ & $\begin{array}{l}\text { No. } \\
\text { Item }\end{array}$ \\
\hline \multirow[t]{6}{*}{$\begin{array}{l}\text { Minat } \\
\text { Belajar }\end{array}$} & \multirow{2}{*}{$\begin{array}{l}\text { Sikap ingin } \\
\text { mengikuti } \\
\text { pembelajaran }\end{array}$} & $\begin{array}{l}\text { Anak menunjukkan sikap } \\
\text { ingin tahu dalam mengikuti } \\
\text { pembelajaran sains }\end{array}$ & Observas & Anak & 1 \\
\hline & & $\begin{array}{l}\text { Anak mengikuti } \\
\text { pembelajaran tanpa disuruh } \\
\text { atau dipaksa }\end{array}$ & Observasi & Anak & 2 \\
\hline & \multirow{2}{*}{$\begin{array}{l}\begin{array}{l}\text { Disiplin } \\
\text { dalam }\end{array} \\
\text { mengikuti } \\
\text { pembelajaran }\end{array}$} & $\begin{array}{l}\text { Anak mencerminkan sikap } \\
\text { taat dan patuh dalam } \\
\text { mengikuti pembelajaran }\end{array}$ & Observasi & Anak & 3 \\
\hline & & $\begin{array}{l}\text { Anak menunjukkan sikap } \\
\text { kemandirian dalam } \\
\text { mengikuti pembelajaran }\end{array}$ & Observasi & Anak & 4 \\
\hline & \multirow{2}{*}{$\begin{array}{l}\text { Mentaati } \\
\text { aturan main } \\
\text { dalam proses } \\
\text { pembelajaran }\end{array}$} & $\begin{array}{l}\text { Anak mau ikut serta dalam } \\
\text { kegiatan pembelajaran dari } \\
\text { awal sampai akhir }\end{array}$ & Observasi & Anak & 5 \\
\hline & & $\begin{array}{lr}\text { Anak } & \text { menunjukkan } \\
\text { perhatiannya } & \text { terhadap } \\
\text { pembelajaran dari awal } \\
\text { sampai akhir }\end{array}$ & Observasi & Anak & 6 \\
\hline
\end{tabular}


J-SANAK: Jurnal Kajian Anak (p-ISSN: 2686-5343 le-ISSN: 2715-7989

Vol. (2)(01), (Juli-Desember)(2020), (Halaman)(1-13)

DOI: https://doi.org/10.24127/j-sanak.v2i01.360

\begin{tabular}{|c|c|c|c|c|c|}
\hline \multirow[t]{6}{*}{$\begin{array}{l}\text { Sikap } \\
\text { Sains }\end{array}$} & \multirow{2}{*}{$\begin{array}{l}\text { Aktivitas } \\
\text { eksploratif } \\
\text { dan } \\
\text { menyelidik }\end{array}$} & $\begin{array}{l}\text { Anak mengamati objek } \\
\text { yang di uji cobakan dalam } \\
\text { pembelajaran sains. }\end{array}$ & Observasi & Anak & 1 \\
\hline & & $\begin{array}{l}\text { Anak mengamati reaksi } \\
\text { objek yang di uji cobakan } \\
\text { dalam pembelajaran sains }\end{array}$ & Observasi & Anak & 2 \\
\hline & \multirow[t]{2}{*}{$\begin{array}{l}\text { Memiliki rasa } \\
\text { ingin tahu } \\
\text { yang tinggi }\end{array}$} & $\begin{array}{l}\text { Anak berani bertanya } \\
\text { seputar pembelajaran sains } \\
\text { yang dipelajari }\end{array}$ & Observasi & Anak & 3 \\
\hline & & $\begin{array}{l}\text { Anak bertanya atau } \\
\text { mengungkapkan sebab } \\
\text { akibat dari reaksi objek } \\
\text { yang di uji cobakan dalam } \\
\text { pembelajaran sains }\end{array}$ & Observasi & Anak & 4 \\
\hline & \multirow[t]{2}{*}{$\begin{array}{l}\text { Pemecahan } \\
\text { Masalah }\end{array}$} & $\begin{array}{l}\text { Anak dapat memecahkan } \\
\text { masalah sederhana dari } \\
\text { kegiatan pembelajaran }\end{array}$ & Observasi & Anak & 5 \\
\hline & & $\begin{array}{lr}\text { Anak } & \text { menyelesaikan } \\
\text { tugas } & \text { meskipun } \\
\text { mendapat } & \text { kesulitan }\end{array}$ & Observasi & Anak & 6 \\
\hline
\end{tabular}

\section{HASIL DAN PEMBAHASAN}

\section{Peningkatan Minat Belajar Anak Secara Klasikal}

Peningkatan minat belajar anak kelompok B Kober Nurjaman Kecamatan Tanjungkerta Kabupaten Sumedang pada pembelajaran sains dengan menggunakan metode eksperimen secara klasikal dapat dilihat pada tabel sebagai berikut:

Tabel 2. Peningkatan Minat Belajar Anak Secara Klasikal pada Kondisi Awal, Siklus I, Siklus II, dan Siklus III

\begin{tabular}{c|c|c|c|c|c}
\hline \multirow{2}{*}{ No } & \multicolumn{2}{|c|}{ Uraian } & \multicolumn{4}{|c}{ Peningkatan Mint Belajar Anak } \\
\cline { 3 - 6 } & $\begin{array}{c}\text { Kondisi } \\
\text { Awal }\end{array}$ & $\begin{array}{l}\text { Siklus } \\
\text { I }\end{array}$ & $\begin{array}{c}\text { Siklus } \\
\text { II }\end{array}$ & $\begin{array}{c}\text { Siklus } \\
\text { III }\end{array}$ \\
\hline $\mathbf{1 .}$ & Rata-rata skor seluruh anak & 1.3 & 2,2 & 3,0 & $\mathbf{3 , 6}$ \\
\hline $\mathbf{2 .}$ & $\begin{array}{l}\text { Kategori minat belajar } \\
\text { seluruh }\end{array}$ & BB & MB & BSH & BSB \\
\hline 3. & $\begin{array}{l}\text { Persentase (\%) anak yang } \\
\text { mencapai minat belajar }\end{array}$ & $0 \%$ & $33 \%$ & $58 \%$ & $\mathbf{9 1 \%}$ \\
\hline $\mathbf{4 .}$ & $\begin{array}{l}\text { Kategori persentase (\%) } \\
\text { anak }\end{array}$ & BB & MB & BSH & BSB \\
\hline
\end{tabular}


J-SANAK: Jurnal Kajian Anak (p-ISSN: 2686-5343 |e-ISSN: 2715-7989

Vol. (2)(01), (Juli-Desember)(2020), (Halaman)(1-13)

DOI: https://doi.org/10.24127/j-sanak.v2i01.360

Peningkatan rata-rata minat belajar anak melalui metode eksperimen pada kondisi awal, siklus I, siklus II, dan siklus III dapat digambarkan dalam diagram batang sebagai berikut

Gambar 1. Diagram Batang Peningkatan Rata-rata Minat Belajar Anak Kelompok B Kober Nurjaman Tahun Pelajaran 2019/2020

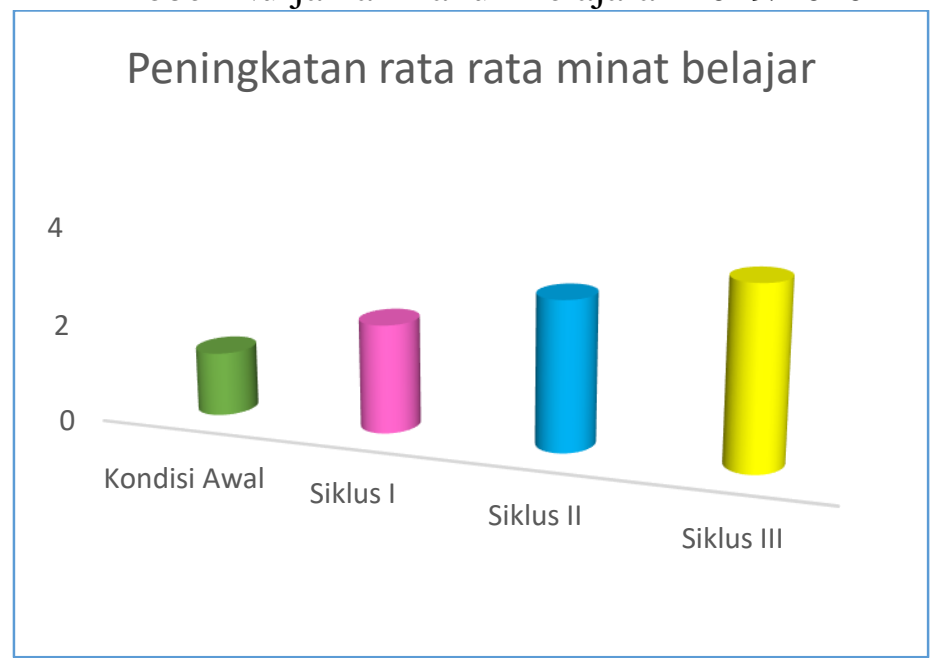

Berdasarkan gambar diagram peningkatan rata-rata peningkatan minat belajar anak di atas yaitu pada kondisi awal sebelum menggunakan metode eksperimen nilai rata-rata hanya mencapai 1,3 setelah menggunakan metode eksperimen dalam pembelajaran sains nilai rata-rata meningkat secara perlahan. Siklus I nilai ratarata mencapai 2,2, siklus II nilai rata-rata menjadi 3,0, dan pada siklus III nilai ratarata meningkat menjadi 3,6.

Berdasarkan tabel di atas, gambaran peningkatan persentase minat belajar anak kelompok B Kober Nurjaman pada kondisi awal, siklus I siklus II, dan siklus III dapat dilihat pada diagram batang sebagai berikut.

Gambar 2. Diagram Batang Peningkatan Rata-rata Prosentase Minat Belajar Anak Kelompok B Kober Nurjaman Tahun Pelajaran 2019/2020

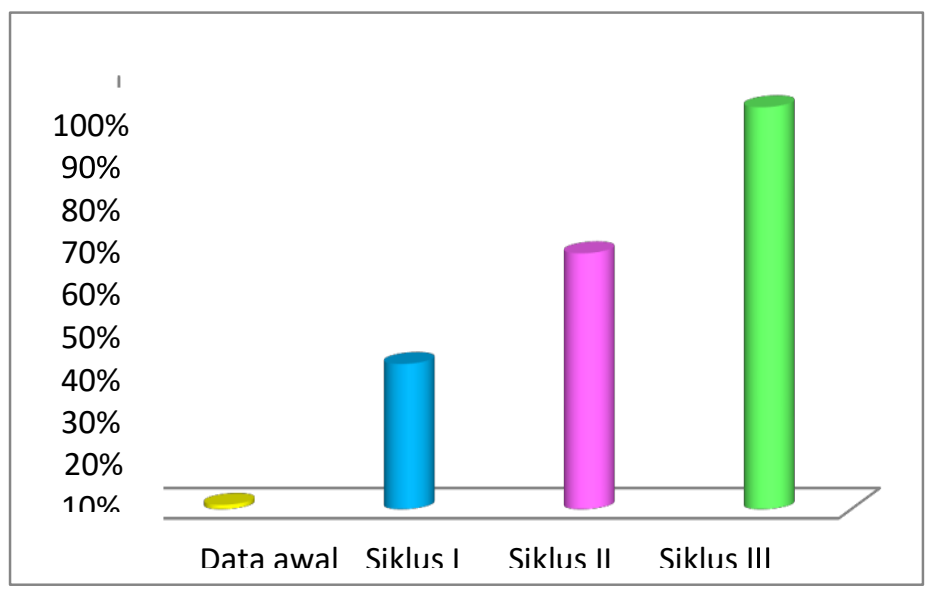

Copyright (C) 2020, Universitas Muhammadiyah Metro| 8 
J-SANAK: Jurnal Kajian Anak

(p-ISSN: 2686-5343 |e-ISSN: 2715-7989

Vol. (2)(01), (Juli-Desember)(2020), (Halaman)(1-13)

DOI: https://doi.org/10.24127/j-sanak.v2i01.360

Berdasarkan gambar di atas peningkatan minat belajar anak dari kondisi awal sampai dengan siklus III mengalami peningkatan yang sangat baik. Dari kondisi awal tidak ada peningkatan sama sekali yaitu $0,0 \%$ kemudian meningkat setelah menggunakan metode eksperimen dalam pembelajaran sains. dari siklus I sebesar 33\%, meningkat kembali pada siklus II menjadi 58\%. Dan pada siklus III meningkat kembali menjadi 91\%. Meningkatnya minat belajar anak dengan menggunakan metode eksperimen sebagaimana hasil penelitian ini dipengaruhi oleh berbagai faktor. Faktor utama dalam meningkatnya minat belajar anak itu sendiri adalah tambahan metode yang digunakan pada penelitian ini. Selain itu, pemilihan jenis kegiatan untuk metode eksperimen yang dipilih dalam pembelajaran sains ini juga menjadi faktor meningkatnya minat belajar anak dalam pembelajaran sains.

\section{Peningkatan Sikap Sains Anak Secara Klasikal}

Peningkatan sikap sains anak kelompok B Kober Nurjaman Kecamatan Tanjungkerta Kabupaten Sumedang pada pembelajaran sains dengan menggunakan metode eksperimen secara klasikal dapat dilihat pada tabel sebagai berikut.

Tabel 3. Peningkatan Sikap Sains Anak Secara Klasikal pada Kondisi Awal, Siklus I, Siklus II dan Siklus III

\begin{tabular}{c|l|c|c|c|c}
\hline \multirow{2}{*}{ No } & \multicolumn{1}{|c|}{ Uraian } & \multicolumn{3}{|c}{ Peningkatan Sikap Sains Anak } \\
\cline { 3 - 6 } & & $\begin{array}{c}\text { Kondi } \\
\text { si }\end{array}$ & $\begin{array}{c}\text { Siklu } \\
\text { s I }\end{array}$ & $\begin{array}{c}\text { Siklus } \\
\text { II }\end{array}$ & $\begin{array}{c}\text { Siklus } \\
\text { III }\end{array}$ \\
\hline 1. & Rata-rata skor seluruh anak & 1 & 2,2 & 3,0 & $\mathbf{3 , 5}$ \\
\hline 2. & Kategori minat belajar seluruh & B & MB & BSH & BSB \\
& anak & B & & & \\
\hline 3. & Persentase (\%) anak yang & 0 & $33 \%$ & $58 \%$ & $\mathbf{9 1 \%}$ \\
& mencapai minat belajar & $\%$ & & & \\
\hline 4. & Kategori persentase (\%) anak & B & MB & BSH & BSB \\
& yang mencapai minat belajar & B & & & \\
\hline
\end{tabular}

Peningkatan rata-rata sikap sains anak melalui metode eksperimen pada kondisi awal, siklus I, siklus II, dan siklus III dapat digambarkan dalam diagram batang sebagai berikut: 
J-SANAK: Jurnal Kajian Anak (p-ISSN: 2686-5343 |e-ISSN: 2715-7989

Vol. (2)(01), (Juli-Desember)(2020), (Halaman)(1-13)

DOI: https://doi.org/10.24127/j-sanak.v2i01.360

Gambar 3. Diagram Batang Peningkatan Rata-rata Sikap Sains Anak Kelompok B Kober Nurjaman Tahun Pelajaran 2019/2020

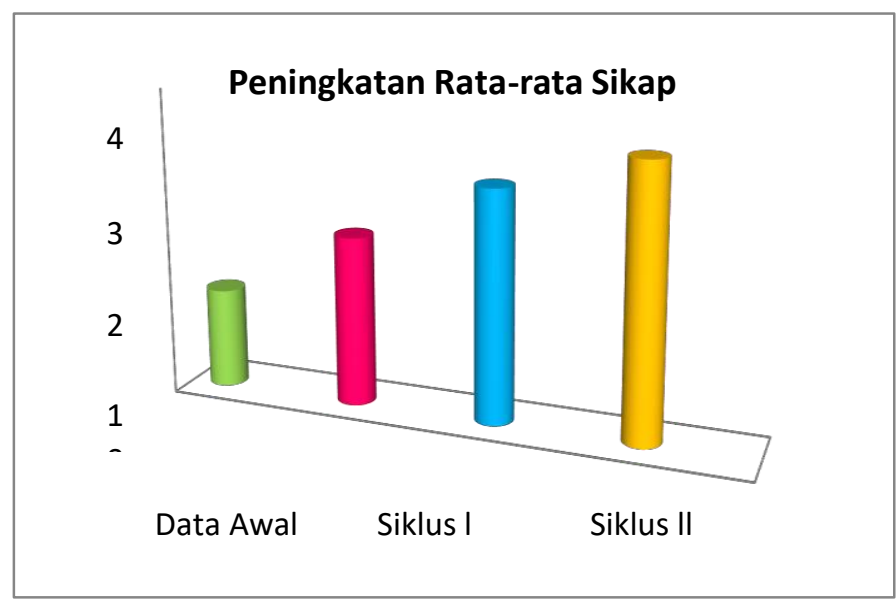

Berdasarkan gambar diagram batang di atas, rata-rata peningkatan sikap sains anak di atas yaitu pada kondisi awal sebelum menggunakan metode eksperimen nilai rata-rata hanya mencapai 1,3 .Sedangkan setelah menggunakan metode eksperimen dalam pembelajaran sains nilai rata-rata meningkat secara perlahan. Siklus I nilai rata-rata mencapai 2,2, siklus II nilai rata-rata menjadi 3,0 dan pada siklus III nilai rata-rata anak mencapai 3,5.

Berdasarkan tabel di atas, gambaran peningkatan persentase sikap sains anak kelompok B Kober Nurjaman pada kondisi awal, siklus I ,siklus II, dan siklus III dapat dilihat pada diagram batang sebagai berikut.

Gambar 4. Diagram Batang Peningkatan Sikap Sains Anak Kelompok B Kober Nurjaman Tahun Pelajaran 2019/2020

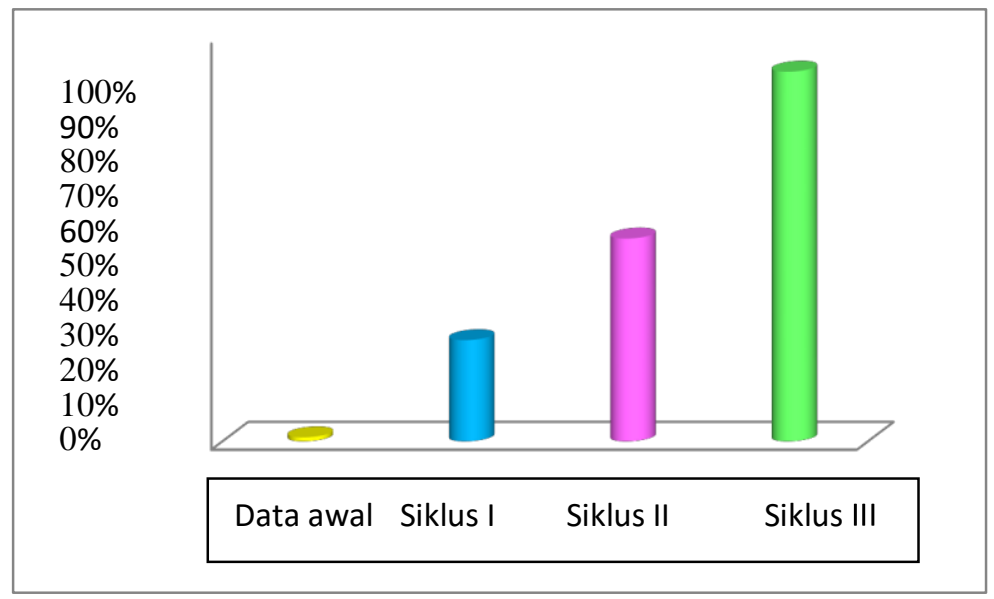

Peningkatan sikap sains anak dari kondisi awal sampai dengan siklus III mengalamin peningkatan yang sangat baik. Dari kondisi awal tidak ada 
J-SANAK: Jurnal Kajian Anak

(p-ISSN: 2686-5343 |e-ISSN: 2715-7989

Vol. (2)(01), (Juli-Desember)(2020), (Halaman)(1-13)

DOI: https://doi.org/10.24127/j-sanak.v2i01.360

peningkatan sama sekali yaitu $0,0 \%$ kemudian meningkat setelah menggunakan metode eksperimen dalam pembelajaran sains. Dari siklus I sebesar $25 \%$, meningkat kembali pada siklus II menjadi 50\% kemudian pada siklus III meningkat kembali hingga mencapai $91 \%$. Meningkatnya sikap sains anak dengan menggunakan metode eksperimen sebagaimana hasil penelitian ini dipengaruhi oleh berbagai faktor. Faktor utama dalam meningkatnya sikap sains belajar anak itu sendiri adalah tambahan metode yang digunakan pada penelitian ini. Selain itu, pemilihan jenis kegiatan untuk metode eksperimen yang dipilih dalam pembelajaran sains ini juga menjadi faktor meningkatnya sikap sains anak dalam pembelajaran sains.

\section{KESIMPULAN}

Penggunaan metode eksperimen dapat meningkatkan minat belajar anak di kelompok B Kober Nurjaman Desa Banyuasih Kecamatan Tanjungkerta Kabupaten Sumedang Tahun Pelajaran 2019/2020. Telah dipaparkan dalam penjelasan hasil penelitian bahwa pada siklus I anak mencapai skor nilai rata- rata 2,2 dengan kategori mulai berkembang (MB), hal ini telah meningkatkan minat belajar anak sebesar 33\%, dikuatkan kembali pada siklus II anak mencapai skor nilai rata-rata 3,0 dengan kategori berkembang sesuai harapan (BSH), hal ini telah meningkatkan minat belajar anak sebesar 58\%, kemudian dikuatkan kembali pada siklus berikutnya yaitu siklus III anak mencapai skor nilai rata-rata hingga 3,6 dengan kategori berkembang sangat baik (BSB), hal ini telah meningkatkan minat belajar anak hingga $91 \%$.

Pembelajaran sains dengan menggunakan metode eksperimen dapat meningkatkan sikap sains anak di kelompok B Kober Nurjaman Desa Banyuasih Kecamatan Tanjungkerta Kabupaten Sumedang Tahun Pelajaran 2019/2020. Telah dipaparkan dalam penjelasan hasil penelitian bahwa pada siklus I anak mencapai skor nilai rata-rata 2,2 dengan kategori mulai berkembang (MB), hal ini telah meningkatkan sikap sains anak sebesar $25 \%$, dikuatkan kembali pada siklus II anak mencapai skor nilai rata-rata 3,0 dengan kategori berkembang sesuai harapan (BSH), hal ini telah meningkatkan sikap sains anak sebesar 50\%, kemudian dikuatkan kembali pada siklus berikutnya yaitu siklus III anak mencapai skor nilai rata-rata hingga 3,5 dengan kategori berkembang sangat baik (BSB), hal ini telah meningkatkan sikap sains anak hingga $91 \%$.

\section{E. DAFTAR PUSTAKA}

Khaeriyah, E., Saripudin, A., \& Kartiyawati, R. (2018). Penerapan Metode Eksperimen Dalam Pembelajaran Sains Untuk Meningkatkan Kemampuan Kognitif Anak Usia Dini. AWLADY: Jurnal Pendidikan Anak, 4(2), 102. 
J-SANAK: Jurnal Kajian Anak

(p-ISSN: 2686-5343 |e-ISSN: 2715-7989

Vol. (2)(01), (Juli-Desember)(2020), (Halaman)(1-13)

DOI: https://doi.org/10.24127/j-sanak.v2i01.360

https://doi.org/10.24235/awlady.v4i2.3155

Ratunguri, Y. (2016). Implementasi Metode Pembelajaran Eksperimen untuk Meningkatkan Keterampilan Proses Sains Mahasiswa PGSD. PEDAGOGIA: Jurnal Pendidikan, 5(2), 137. https://doi.org/10.21070/pedagogia.v5i2.243

Roostin, E. (2015). Analisis Kemunculan Sikap Sains Pada Anak Usia Dini Di Tk Negeri Centeh Kota Bandung. Pedagogik-Pendas, 474. http://jurnal.upi.edu/pedagogik-pendas/view/3432/analisis-kemunculansikap-sains-pada-anak-usia-dini-di-tk-negeri-centeh-kota-bandung.html

Roostin, E., \& Swandhina, M. (2019). Analisis Pembelajaran Sains Pada Anak Usia Dini Berbasis Karakter Di TK Arasy Kabupaten Sumedang. Online), 5(2), 2581-0413. siliwangi/article/view/1360

Slameto. (2015). Belajar dan Faktor-faktor yang Mempengaruhinya. Rineka Cipta. Suharsimi, A. (2006). Prosedur penelitian suatu pendekatan praktik. Jakarta: Rineka Cipta. 